Grant-in-Aid for Scientific Research (S)

Real Estate Markets, Financial Crisis, and Economic Growth

: An Integrated Economic Approach

Working Paper Series No.22

Regional Inflation and Financial Dollarization

\author{
Martin Brown \\ Ralph De Haas \\ and \\ Vladimir Sokolov
}

J une, 2015

HIT-REFINED PROJ ECT

Institute of Economic Research, Hitotsubashi University

Naka 2-1, Kunitachi-city, Tokyo 186-8603, J APAN

Tel: +81-42-580-9145

E-mail: hit-tdb-sec @ier.hit-u.ac.jp

http://www.ier.hit-u.ac.jp/ifn/ 


\title{
Regional Inflation and Financial Dollarization
}

\author{
Martin Brown*, Ralph De Haas**, and Vladimir Sokolov***
}

\begin{abstract}
We exploit variation in consumer price inflation across 71 Russian regions to examine the relationship between the perceived stability of the domestic currency and financial dollarization. Our results show that regions with higher inflation experience an increase in deposit dollarization and a decrease in the dollarization of loans to households and firms in non-tradable sectors. The negative impact of inflation on credit dollarization is weaker in regions with less integrated banking markets. This suggests that the asset-liability management of banks constrains the currency-portfolio choices of both households and firms without a natural currency hedge.
\end{abstract}

JEL codes: E31, E42, E44, F36, G21, P22, P24

Keywords: Financial dollarization, financial integration, regional inflation

\footnotetext{
*University of St. Gallen, martin.brown@unisg.ch. **European Bank for Reconstruction and Development and Tilburg University, dehaasr@ebrd.com. ***Higher School of Economics Moscow, vsokolov@hse.ru. The authors would like to thank Cagatay Bircan, Sergei Guriev, Lukas Menkhoff, Alexander Plekhanov, Koen Schoors, Maria Semenova, Assaf Razin, Laura Solanko, Neven Valev, Jeromin Zettelmeyer, and seminar participants at Cass Business School, the EBRD and the Higher School of Economics for useful comments. The views are those of the authors and do not necessarily reflect those of the EBRD.
} 


\section{Introduction}

Financial dollarization, the widespread holding of assets and liabilities in a foreign currency, is viewed as both a constraint on monetary policy and a threat to financial stability in many emerging markets. In the aftermath of the financial crisis, policy makers have emphasized the need for de-dollarization (or de-euroization) of deposits and loans, particularly in Latin America and eastern Europe (Garcia-Escribano and Sosa, 2011). A credible monetary policy with low and stable consumer price inflation, such as through an inflation targeting regime, is seen as a key ingredient to kick-start dedollarization. The objective of this paper is to examine how and to what extent the stability of the domestic currency affects the propensity of both firms and households to hold foreign currency assets (deposits) and liabilities (loans).

We exploit variation in consumer price inflation across Russian regions to examine the relationship between the perceived stability of the domestic currency and financial dollarization. Our analysis is based on quarterly data on asset and liability dollarization as well as on local consumer price inflation for 71 regions over the period 2005:Q2 to 2014:Q2. This is an interesting period to analyze as exogenous factors, particularly food and oil price spikes, caused substantial cross-regional and time variation in Russian inflation. Moreover, a year before the start of our observation period, Russia introduced a comprehensive deposit insurance scheme which led to a rapid increase in household deposits. The scheme significantly reduced households' sensitivity to bank-specific risk (Karas, Pyle, and Schoors, 2013), giving further prominence to monetary risks in households' deposit allocation decisions.

Our within-country data allow us to tackle two shortcomings of previous studies that rely on cross-country data. Firstly, unobserved heterogeneity in economic policies and institutions may cloud the cross-country relationship between monetary conditions and dollarization. We alleviate this concern by examining cross-regional variation within a country with a common 
macroeconomic policy and institutional framework. Secondly, cross-country studies cannot disentangle the impact of inflation on dollarization from that of (correlated) changes in exchange rates. We can isolate the impact of inflation on financial dollarization given that exchange rate movements are uniform over all regions within the currency union of the Russian Federation.

We show that regions with high inflation experience higher deposit dollarization and lower dollarization of (long-term) household credit and loans to firms in non-tradable sectors. The impact of inflation on credit dollarization is weaker in regions which are financially less integrated with the rest of the Russian Federation - that is to say, regions with a higher share of local banks or local bank branches and regions where banks are more reliant on local funding. In such regions the negative impact of inflation on the demand for foreign currency loans is partially offset by banks' efforts to locally intermediate the increased supply of foreign currency deposits. In contrast, in regions with more nationwide banks and banks that are not locally funded, an inflation-driven influx of foreign currency deposits can be easily distributed to other regions, reducing the need to offload them locally. Such integrated banking markets therefore allow households and firms to respond to inflation shocks by adjusting both their assets and liabilities whereas the asset-liability management of banks constrains the currency-portfolio choices of these agents in less-integrated banking markets.

Our results provide partial support to the portfolio theory of financial dollarization (Ize and Levy Yeyati, 2003). This theory argues that the currency composition of assets and liabilities of risk-averse households is determined by real interest rate differentials as well as the volatility of inflation and of the real exchange rate. ${ }^{1}$ In line with this theory, we find that higher inflation and

\footnotetext{
${ }^{1}$ When the uncovered interest rate parity holds (no real interest rate differential) the currency composition of assets and liabilities is determined by the minimum variance portfolio (MVP). In the case of deviations from the uncovered interest parity households deviate from the MVP
} 
therefore lower real interest rate differentials are associated with more (less) foreign currency deposits (loans). We find some evidence that variation in inflation volatility across regions impacts on foreign currency deposits but not on foreign currency loans.

Our contribution to the literature is threefold. Firstly, we complement crosscountry studies which examine the relationship between domestic monetary conditions and financial dollarization. ${ }^{2}$ Examining aggregate data for 46 countries for the years 1990-95, Ize and Levy Yeyati (2003) find that the share of foreign currency deposits is positively related to inflation volatility and negatively related to exchange rate volatility. De Nicoló et al. (2005) examine a sample of 100 countries for the period 1990-2001 and confirm the impact of inflation and exchange rate volatility on aggregate deposit dollarization. They also find that high inflation is associated with more dollarization. More recently, Lin and Ye (2013) document that adoption of inflation targeting in emerging market countries results in a decline in dollarization compared to a matched sample of countries without an inflation-targeting regime. For emerging Europe, Luca and Petrova (2008) find that aggregate shares of foreign currency loans are positively related to interest rate differentials and inflation volatility whereas they are negatively related to exchange rate volatility. These results are confirmed by Basso et al. (2010) who examine aggregate credit and deposit dollarization for 24 transition countries for the period 2000-06. Our contribution to this literature is to examine cross-regional variation within the same macroeconomic and institutional framework. This reduces concerns about omitted unobserved heterogeneity and allows us to

- they decrease (increase) the share of FX deposits (loans) as the real interest rate differential between the local and foreign currency widens. See Froot and Thaler (1990) for evidence on deviations from the uncovered interest parity.

2 Özbilgin (2012) provides a within-country analysis of the relation between inflation and financial dollarization for Turkey based on a DSGE model. 
empirically isolate the impact of inflation on dollarization from that of (correlated) exchange rate movements.

Secondly, we provide new insights into how inflation impacts financial intermediation. Boyd et al. (2001) document a negative relationship between inflation (once it surpasses a certain threshold) and banking development at the country level. Lower real returns exacerbate credit market frictions, increase credit rationing, and limit the depth of the banking sector. De Nicoló et al. (2005) show, also at the country level, that deposit dollarization moderates this adverse effect of inflation as dollarization allows households to keep deposits onshore when they face high inflation. We document how inflation affects the interaction of the demand for and supply of foreign currency funds between banks on the one hand and households and firms on the other hand. In particular, we are the first to show how the impact of inflation on dollarization depends on interregional banking integration.

Thirdly, our analysis contributes to the growing literature on regional inflation disparities within currency unions. Beck et al. (2009) compare the size and persistence of regional inflation differentials in the euro-zone and the US and show that such differentials are larger and more persistent in the euro-zone. Regional inflation differences in both currency unions are related to structural characteristics of non-labor factor markets rather than labor market frictions or growth dynamics. Nagayasu (2011) and Vaone and Ascari (2012) confirm the persistence of regional inflation differences for Japan and Italy respectively. We add to this literature by documenting how regional inflation variation may lead to the differential use of the common currency by households.

The paper is structured as follows. Section 2 discusses the theoretical relationship between regional inflation and financial dollarization after which Section 3 describes our data and empirical strategy. Section 4 then presents our results on the link between regional inflation and dollarization and how this link depends on regional financial integration. Section 5 concludes. 


\section{Regional Inflation and Financial Dollarization: Theory}

Theories of financial dollarization have rationalized the use of foreign currency as a medium of payments (currency substitution) and as a medium to store wealth (asset substitution). As households use deposits for transaction as well as storage purposes, both currency and asset substitution provide useful theoretical frameworks to guide our empirical analysis. In this section we therefore discuss how consumer price inflation affects household currency choice in models of currency and asset substitution, respectively. More precisely, we discuss how regional inflation impacts the currency choice of depositors, borrowers and intermediaries in a setting where both interest rates and exchange rates are set nationally.

The currency substitution theory (e.g. Uribe, 1997 and Engineer, 2000) suggests that agents choose the foreign versus domestic currency as a means of payment by trading off the purchasing power risk of domestic currency versus the transaction costs of using foreign currency. ${ }^{3}$ Foreign currency is more likely to be used as a medium of exchange if the expected depreciation of the domestic currency is high. Thus for consumer price inflation to have an impact on currency substitution at the regional level we need to consider a framework in which households' depreciation expectations are at least partly related to observed inflation at the regional level.

Models which allow for heterogeneous signals of monetary developments across agents provide such a framework (Phelps, 1970; Lucas, 1972; Morris and Shin, 2002; Myatt and Wallace, 2014). ${ }^{4}$ Suppose that households base

${ }^{3}$ Craig and Waller (2004) endogenize the transaction costs of using foreign currency in a model with network effects. Valev (2010) provides household-level evidence for Bulgaria suggesting that network effects have a stronger influence on currency substitution than variation in individual exchange rate expectations.

${ }^{4}$ See Bacchetta and van Wincoop (2006) for a model which combines dispersed information about fundamentals and heterogeneous investor behavior and Winkelried and Castillo (2010) 
their exchange rate expectations on economy-wide public signals - such as past exchange rate developments ${ }^{5}$ and monetary-policy statements - as well as heterogeneous, private, and local signals. If locally observed consumer prices serve as a private signal for depreciation risk, we would expect households in regions with high (or increasing) regional inflation to increase their holding of foreign currency as a means of payment. This would lead to an increase in the holding of foreign currency (as opposed to domestic currency) bank deposits, but also to an increase in the holding of foreign currency cash.

According to the portfolio theory of asset substitution (Ize and Levy Yeyati, 2003) households' currency choices for bank deposits are driven by the expected real return and real valuation risk on foreign currency vs. domestic currency deposit contracts. This theory predicts first that the share of deposits held in foreign currency will increase with the expected real interest rate differential on foreign vs. local deposits. In line with our reasoning above, higher local consumer price inflation may be associated with a higher real return on foreign currency deposits if it serves as a private signal of exchange rate depreciations. This would be particularly the case if the nominal interest rates on deposits are set homogenously across all regions. ${ }^{6}$

The portfolio theory argues that in addition to the difference in expected real returns, risk-averse households will consider the variance in the real value of

for a model of how noisy exchange-rate signals can lead to persistent financial dollarization in an economy with heterogeneous agents. Fratzscher et al. (2015) provide an empirical analysis of scapegoat models in which agents associate unobserved trading shocks with observable fundamentals.

5 See Brown and Stix (2014) for evidence on the hysteresis of monetary expectations in developing economies.

${ }^{6}$ While interest rates differ across local Russian banks, the rates of branches of the main nation-wide state banks -in particular Sberbank and VTB- are uniform. Sberbank and VTB capture about 50 and 6 percent of the Russian deposit market, respectively, and are present in all regions. Both banks offer the same deposit terms in all locations. 
foreign currency vs. domestic currency deposits. The minimum variance portfolio will hereby be characterized by a higher share of foreign currency deposits as the variance of nominal inflation increases and the variance of the real exchange rate decreases. Thus, the portfolio theory suggests that not only a higher level of regional inflation may be associated with an increase in the holding of dollarized deposits, but also - all else equal - a higher volatility of regional inflation.

The portfolio theory also provides a framework to discuss how regional inflation may affect the demand for foreign currency loans from (unhedged) borrowers. Higher expected real borrowing costs for foreign currency loans as opposed to domestic currency loans should lower demand for the former. Again, if regional inflation provides a (private) signal for expected depreciation it would decrease foreign currency demand from households and firms which rely on domestic currency income. Beckmann and Stix (2014) document that households which expect a domestic currency depreciation are less likely to demand foreign currency loans.

In sum, both the currency substitution and the portfolio theory predict that high regional inflation increases FX deposits if households interpret the region-specific inflation they experience as a private signal of imminent exchange-rate deprecation. Analogously, the portfolio theory suggests that higher regional inflation may also lead to a reduction in the demand for FX loans. In the remainder of this paper we put these predictions to the test. 


\section{Data and Methodology}

\subsection{Data}

The units of our analysis are 71 federal 'subjects' of the Russian Federation (referred to henceforth as regions). ${ }^{7}$ We collect quarterly end-of-period data on both consumer price inflation and credit and deposit dollarization in each of these regions from the Central Bank of Russia (CBR) and the Federal State Statistics Service (Rosstat).

Our data are particularly well suited for testing the impact of regional inflation on dollarization. To facilitate cross-regional analysis and provide a consistent purchasing power measure, Rosstat has devised a consumer price index that tracks monthly price dynamics of a fixed basket of consumer goods and services across all Russian regions. We use this index to calculate for each region and for each quarter a year-on-year (y-o-y) inflation rate and inflation volatility. We define the latter as the standard deviation of the monthly price index in the twelve months before the end of a quarter.

Figure 1 shows the cross-regional dispersion and time-variation in Russian inflation that we exploit in this paper. Individual observations indicate the deviation from the country-sample mean of the y-o-y consumer price index (CPI). As we use a uniform consumer goods basket for all regions, regional dispersion does not reflect different weights. By way of comparison, we present similar data for two other large currency unions - the eurozone (12 countries) and the U.S. (25 metropolitan areas).

\footnotetext{
7 There are 83 federal subjects in Russia. From our analysis we exclude three regions that contain autonomous districts (Nenetsk, Hanty-Mansiysk, and Yamalo-Nenetskiy) as the district data are part of the consolidated regional data. We also exclude two federal cityregions (Moscow and St. Petersburg) and, due to severe data limitations, the North-Caucasian conflict zones Chechnya, Dagestan, Ingushetia, North Ossetia, Kabardino-Balkaria, KarachayCherkessia and Adygea. This leaves us with 71 regions.
} 
The data show that in Russia, as in the U.S. and the eurozone, cross-sectional variation in inflation across regions is substantial and at least as high as the time variation. For instance, in the first quarter of 2006 the median regional yo-y inflation rate in Russia was 14.38 percent but ranged between 5.84 and 20.80 percent across regions. This regional inflation dispersion was also persistent. Throughout the sample period the difference between the highest and the lowest regional inflation rate in a quarter was on average 14.34 percentage points. ${ }^{8}$

The high persistence in regional inflation differences reflects, among other things, the continuation of administrative (mainly food) price controls by local authorities and temporary restrictions on inter-regional exports and imports, as well as informal trade restrictions resulting from organized crime that block imports in order to maintain local rents. Moreover, Russia's nation-wide infrastructure for the marketing, distribution and selling of consumer goods is still limited, leading to relatively regionalized markets (Gluschenko, 2001).

The sample contains three periods in which inflation accelerated - early 2005, mid-2008, and mid-2010 to mid-2011. All three episodes were driven by external factors. ${ }^{9}$ The first spike was caused by a sharp increase in the price of heating services which coincided with rising oil prices. The second and third spikes were largely driven by food inflation. World food prices accelerated dramatically in 2007-08 following droughts in a number of grain-producing countries, the increased use of bio-fuels and high oil prices which raised

\footnotetext{
${ }^{8}$ This is consistent with a recent analysis of regional price dispersion by Gluschenko (2013) for the period 2001-10. For evidence on cross-regional price conversion in the earlier years of transition (1994-2000), see Gluschenko (2010).

${ }^{9}$ While Russia's 2004 capital account liberalization lifted all restrictions on foreign currency transactions by residents and non-residents, there were no dramatic changes in monetary policy during the period we study (though the authorities did react to an overheating economy by raising the policy rate in 2008).
} 
transportation and fertilizer costs. Summer droughts in 2010 again pushed up food prices. These dynamics played out differently across Russia depending on regional natural resource endowments and infrastructure quality.

\section{[Insert Figure 1 around here]}

Figure 2 shows geographical 'heat maps' of average inflation as well as deposit and credit dollarization across regions. The first panel displays average consumer inflation over the period Q2 2004-Q2 2014. The substantial crossregional variation in average inflation is again apparent. Importantly, behind these averages also lies substantial within-region variation over time. For instance, in Q2 2014 consumer price inflation in the Kurk region was 2.3 percentage points higher than in Q2 2004, while it declined by 28.9 percentage points in Kamchatka over the same period.

\section{[Insert Figure 2 around here]}

We obtain our data on bank deposits and on credit to firms and households from the CBR. The central bank requires all commercial banks to submit detailed information on their quarterly activities by geographical location. These region-specific banking data are classified by client type (households or firms) and by currency denomination (domestic or foreign). This allows us to trace how regional consumer inflation affects the currency denomination of new household deposits and loans with banks. ${ }^{10}$

\footnotetext{
10 All banks in Russia offer multi-currency deposits that allow retail customers to easily convert savings between different currencies through automatic teller machines (ATM) or online accounts. A competitive deposit market has made conversion costs quite low.
} 
For our analysis we employ information on net deposit flows from households to banks as well as new bank loans to firms and households. We can thus relate changes in inflation across regions to the currency denomination of the flows of assets and liabilities. Data on net deposit flows by households are available since Q2 2005 which sets the beginning of our sample period. Our sample ends in Q2 2014 and we exclude the crisis year Q3 2008-Q3 2009.

For each region and quarter the variable Deposit dollarization measures the ratio of net deposit inflows denominated in foreign currency as a share of total net deposit inflows to banks. The second panel of Figure 2 shows the average share of net deposits in foreign currency. As with inflation, there is substantial variation in average deposit dollarization across regions and over time.

The variable Mortgage dollarization measures the share of newly extended mortgages in foreign currency as a share of total new mortgage loans by banks. Mortgages in Russia typically have fixed rather than variable nominal interest rates, making inflation expectations at the time of the signing of the mortgage contract a potentially important determinant of the preferred currency of denomination. FX mortgage lending dried up quickly and completely when the global financial crisis hit Russia towards the end of 2008 (World Bank, 2013, p. 54-55) and our sample period for mortgage dollarization therefore ends in Q2 2008.

Lastly, the variable Corporate debt dollarization measures the share of newly extended firm credit in foreign currency as a share of total new lending to firms. We distinguish between the dollarization of new lending to firms in tradable versus those in non-tradable sectors, using the classification of Jensen and Kletzer (2005). We expect that firms have different exchange rate exposures according to whether they sell in domestic or foreign markets.

According to central bank statistics the average bid-ask spread for rouble-US\$ retail transactions was 1.63 percent during the period of our study. 
Exporters, with a (full or partial) natural hedge against the currency risk associated with FX-denominated debt, typically match the currency denomination of their liabilities with that of their incoming cash flows. Their demand for FX loans will be relatively insensitive to local inflation. In contrast, we expect that (unhedged) firms in non-tradable sectors behave more like households. Their demand for FX loans may be more sensitive to regional inflation and to changes in the supply of FX loans by local banks. ${ }^{11}$

The third panel of Figure 2 shows the average share of newly extended FX loans to Russian firms in non-tradable sectors as a share of total new bank lending to these firms. We observe again substantial cross-regional variation. For instance, the average quarterly change in this share of FX lending was -4.85 percent in the Leningrad region but 38.9 percent in the Murmansk region. Within regions there was also strong variation over time. For instance, the proportion of new lending to non-tradable firms denominated in FX increased by 43.56 percent in the Tambov region during our sample period while it declined by 17.26 percent in the Amur region.

These and all other variables we use in our analysis are defined and summarized in Appendix Tables A1 and A2. The dependent variables are calculated on a constant currency basis by using the exchange rate change over the reported period to adjust the reported FX amounts. With the exception of the regional proportion of local banks and local deposit funding, we winsorize variables at the $1^{\text {st }}$ and $99^{\text {th }}$ percentiles.

\footnotetext{
${ }^{11}$ Evidence from a large number of developing countries suggests that firms in non-tradable sectors experience an increase in currency mismatches during boom periods when banks provide them with relatively cheap FX loans (Rancière, Tornell, and Vamvakidis, 2010).
} 


\subsection{Methodology}

As discussed in Section 2, both the currency substitution and the portfolio theories of financial dollarization predict that high inflation increases FX deposits. The portfolio theory also predicts a reduction in the demand for FX loans while suggesting that high inflation volatility and low volatility of the real exchange rate result in a high share of both FX assets and liabilities.

Section 2 also highlighted two channels through which regional inflation can affect dollarization. First, given that interest rates on loans and deposits (for domestic currency and foreign currency funds) are largely homogeneous across Russia, higher regional inflation implies lower real interest rate differentials. Therefore, for given exchange rate expectations, higher regional inflation should encourage households to save in foreign currency and borrow in domestic currency. Second, regional inflation may serve as a (noisy) signal of future exchange rate developments. If higher observed inflation in a region leads households to expect a depreciation of the domestic currency, then for given interest rates households will be more likely to save in foreign currency and borrow in domestic currency. Based on these considerations we estimate the following empirical model:

$$
\Delta F X_{i t}=\alpha_{t}+\alpha_{i}+\beta_{1} \cdot I N F L_{i t-1}+\beta_{2} \cdot I N F L_{-} V O L_{i t-1}+\gamma \cdot X_{i t}+\varepsilon_{i t}
$$

The dependent variable $\Delta F X_{i t}$ is the share of either net deposits flows, newly extended firm credit, or newly extended mortgages that is denominated in foreign currency in a region $i$ in quarter $t$. Inflation $\left(I N F L_{i t-1}\right)$ as well as inflation volatility $\left(I N F L_{-} V O L_{i t-1}\right)$ are expected to impact these regional dollarization variables and we therefore include both, either separately or jointly (the pair-wise correlation coefficient between both variables is 0.29). Both inflation and inflation volatility are included one quarter lagged to allow for a gradual pass through. Note that as we use past inflation as an indicator of 
future inflation, we implicitly assume that inflation expectations are adaptive in nature (Fuhrer and Moore, 1995).

Exchange rate volatility and interest rates are homogenous across regions and absorbed by time fixed effects $\alpha_{t}$. The region fixed effects $\alpha_{i}$ account for (timeinvariant) differences in the risk aversion of households across regions, as well as the persistent part of cross-regional inflation differentials. Such persistent differentials can reflect different income levels (the Balassa-Samuelson effect) as well as frictions in factor markets (Beck et al. 2009). We estimate all regression specifications using robust standard errors clustered by region in order to control for possible residual correlation across time for a given region. The vector $X_{i t}$ captures time-varying regional characteristics which may simultaneously drive changes in regional inflation and dollarization. According to the literature on the determinants of regional inflation these could include changes in economic structure and/or changes in local factor market frictions. We therefore include trade openness (quarterly growth of regional trade (imports plus exports) with foreign countries); the value of tradable goods (quarterly growth of the regional value added of the manufacturing and commodity-extraction industries); and the value of nontradables (quarterly growth of the regional value added of the construction, electricity generation, services, retail, and wholesale trade industries) as control variables in our empirical model.

Regional inflation and financial dollarization might also be correlated because both are impacted by local fiscal policy which differs across regions and over time. For example, De Gregorio (1994) demonstrates that public expenditures can induce an increase in the relative price of non-tradables. Fiscal transfers to specific household types may also alter the currency denomination of their savings. In order to control for these effects we include the y-o-y growth of regional government spending as an additional covariate in $X_{i t}$. 
$X_{i t}$ also contains four dummy variables which account for the entry and exit of regional or multiregional banks over the previous year. These dummies are switched on if there is an increase or a decrease in the number of locally incorporated banks or an increase or a decrease in the number of branches of banks incorporated in another region. We hereby control for sudden changes in the local banking landscape which may lead to one-off 'jumps' in dollarization on either the asset or liability side of the regional banking system.

\subsection{Accounting for Financial Integration}

Russia's regions vary considerably with respect to how strongly the regional banking sector is integrated with the rest of the financial sector. We employ four indicators to measure the degree to which the banking sector in a region is integrated or closed. First, we calculate the share of locally incorporated banks (Proportion local banks $)_{i}$ ) in the total number of banks in a region (i.e. local and inter-regional banks). Second, we take the share of branches of locally incorporated banks (Proportion local bank branches ( $_{i}$ in the total number of bank branches in a region. Third, we compute the share of a region's bank liabilities that are on the balance sheet of locally incorporated banks (Proportion local bank liabilities $)_{i}$ ). Fourth, we use the percentage of regional household deposits in total external bank funding, i.e. the sum of household deposits, firm deposits, and net credit from other banks (Proportion deposit funding $_{i}$ ). These indicators are time-invariant and measured prior to our observation period to mitigate concerns of endogeneity. ${ }^{12}$

On average, nearly one-third of the banks operating in any region in Russia are local and operate in that region only. However, the share of local banks varies between zero and 73 percent (see Table A2). The share of branches operated by local banks is 7 percent on average but again this varies from zero to 50

\footnotetext{
${ }^{12}$ The exception is Proportion local bank branches shich $_{\text {is }}$ measured for 2012 due to a lack of earlier data.
} 
percent across regions. Therefore, only nation-wide banks operate in some regions whereas in other regions the majority of banks and bank-branches are local. This variation is also reflected in the proportion of bank liabilities that are held by local banks. This proportion varies between zero and 94 percent. Our data also show similar variation in terms of banks' reliance on retail deposits. On average 41 percent of bank liabilities are made up of customer deposits. But in some regions the share of retail deposits is a mere 9 percent whereas in others it amounts to 68 percent.

We exploit the regional heterogeneity in banking sector integration to test the conjecture that the negative impact of inflation on credit dollarization should be weaker in regions with less-integrated banking sectors. The reasoning is that in regions with less integrated banking sectors, banks cannot allocate FX funds across regions, neither via external markets nor through internal capital markets. ${ }^{13}$ This means that if banks aim to avoid currency mismatches on their balance sheet, local FX bank deposits need to be intermediated into local FX credit (e.g. Calvo, 2001). The minimum variance portfolio of local households is then the only possible financial equilibrium (Ize and Levy Yeyati, 2003). In contrast, deviations from local MVP occur more easily when banks are regionally integrated as the local supply and demand of FX funds need not coincide. This is because inflation incentivizes households to supply banks with FX deposits but also to demand more domestic currency lending. This implies that financially integrated banking systems allow households to deviate more from MVP and thus to better adjust their currency portfolio.

13 Evidence from the U.S. (Morgan, Rime, and Strahan, 2004 and Loutskina and Strahan, 2015); Japan (Imai and Takarabe, 2011) and the Netherlands (Cremers, Huang and Sautner, 2011) indicates that nation-wide banks actively reallocate funds across regions within one and the same country. 
The above hypothesis relies on the assumption that banks in regions with closed banking sectors manage on-balance-sheet currency risk by adjusting the currency structure of their loans to that of the (given) currency structure of their deposits. Recent evidence suggests that this is the case in many emerging markets. Brown and De Haas (2012) as well as Brown et al. (2014) document that the currency structure of customer deposits (rather than the currency structure of wholesale funding) is a crucial driver of the currency structure of banks' loan portfolios. Brown, Kirschenmann and Ongena (2014) argue that a large share of foreign currency retail loans in Eastern Europe is supply-driven, as banks are eager to match the currency structure of their assets and liabilities. Anecdotal evidence confirms that Russian banks that experience an increase in FX deposit inflows react by extending more loans in FX. ${ }^{14}$ While banks could in principle place FX deposits in their correspondent account at the central bank or in the interbank market, they would have to forego a substantial amount of interest income.

Based on this evidence we expect that the impact of inflation across Russian regions on the dollarization of household deposits is independent of the integration of the banking market, while the impact of inflation on loans to households and firms in the non-tradable sectors is less negative in regions with closed bank sectors. We empirically test this prediction by augmenting our baseline specification with an interaction term of inflation with one of four measures of regional banking integration. Equation (2) captures our augmented empirical model in which $I N F L_{i, t-1}{ }^{*}$ Fin_Closed $_{i}$ is the interaction term of interest. In our estimations of credit dollarization we expect the

14 The Russian business press regularly highlights this phenomenon (e.g. http://www.gazeta.ru/business/2014/10/30/6283285.shtml) and stresses in particular that banks that experience an influx of FX deposits allocate part of this new FX funding to businesses in non-tradable sectors that may not have a natural hedge (unlike these banks' regular FX borrowers such as large exporters with guaranteed FX contracts). 
coefficient of the interaction term to be positive: the impact of inflation on credit dollarization will be less negative in regions with non-integrated banking sectors. ${ }^{15}$ By contrast, in our estimation of deposit dollarization we expect the interaction term to be insignificant.

$$
\Delta F X_{i t}=\alpha_{t}+\alpha_{i}+\beta_{1} \cdot I N F L_{i t-1}+\beta_{2} \cdot I N F L_{i t-1} \cdot \text { FIN_Closed }_{i}+\beta_{3} \cdot I N F L_{-} V O L_{i t-1}+\gamma \cdot X_{i t}+\varepsilon_{i t}
$$

\section{Results}

\subsection{Inflation and Dollarization - Baseline Results}

We report our baseline results in Table 1. As dependent variables we use the dollarization of the net flow of households' deposits (columns 1-3) and of new corporate lending (columns 4-9). We split up corporate lending into loans to firms in non-tradable versus tradable sectors. All specifications include region and time (i.e. quarter) fixed effects.

The key message that emanates from Table 1 is that, in line with portfolio theory, higher regional inflation is associated with more foreign currency deposits and less foreign currency lending. The impact of inflation on dollarization is substantial. A one standard deviation (s.d.) increase in regional year-on-year inflation is associated with a 0.16 s.d. increase in deposit dollarization in the next quarter and a 0.13 s.d. decrease in the dollarization of loans to non-tradable firms. As expected, columns 7-9 do not show an effect of inflation on the currency denomination of loans to firms in tradables sectors. As discussed previously, exporters and importers tend to carefully match the currency denomination of their loans with the currency denomination of their incoming cash flows.

\footnotetext{
${ }^{15}$ The main terms of our cross-sectional measures of financial integration are absorbed in the region fixed effects $a_{i}$.
} 
When we include inflation volatility separately (columns 2 and 5) it has a positive impact on deposit dollarization, in line with what one would expect on the basis of portfolio theory, but no significant impact on corporate dollarization. When we add both variables at the same time (columns 3 and 6) both the level and the volatility of inflation enter significantly in the deposit regressions while the inflation level wins this horse race in the case of corporate lending (although the imprecisely estimated coefficient for inflation volatility is positive here too, in line with theory).

\section{[Insert Table 1 here]}

\subsection{The role of regional financial integration}

In Table 2 we analyze how the relationship between regional inflation and dollarization is affected by the local banking structure. The results in columns 1-4 confirm that the impact of inflation on deposit dollarization is independent of how integrated the local banking sector is. The interaction terms Inflation*Proportion local banks (column 1); Inflation*Proportion local bank branches (column 2); Inflation*Proportion deposit funding (column 3); and Inflation*Proportion local bank liabilities (column 4) are weak both in terms of statistical significance and economic magnitude.

In columns 5-8 we examine the impact of banking sector integration on credit dollarization. We expect that in regions with less-integrated banking systems higher inflation -and the resulting larger FX deposit base- partially offsets the negative direct effect of inflation on credit dollarization. The results in columns 5-8 show exactly this: The positive and significant interaction terms for Inflation*Proportion local banks; Inflation*Proportion local bank branches; Inflation*Proportion deposit funding; and Inflation*Proportion local bank liabilities, together with the negative main effect of Inflation, suggest that the negative impact of inflation on corporate loan dollarization is 
weaker in regions with non-integrated banking sectors. ${ }^{16}$ Again, we find no such effects for lending to firms in tradable sectors (columns 9-12).

Financial integration has a sizeable impact on the relation between inflation and credit dollarization. The estimates in column 5 suggest that for the region with the lowest proportion of local banks (6 percent in the Penza region), a one s.d. increase in inflation reduces corporate credit dollarization by 0.24 s.d. By contrast, for a region with the highest proportion of local banks (73 percent in the Altai region) the negative effect of inflation on corporate credit dollarization disappears altogether.

\section{[Insert Table 2 here]}

Taken together, the results in Table 2 indicate that the impact of price instability on credit dollarization depends on the structure of the local banking system. The impact is strongest if banks are more integrated with the rest of the Russian economy. ${ }^{17}$

\footnotetext{
${ }^{16} \mathrm{We}$ also estimate a specification where we define local banks as domestic (as opposed to foreign-owned) banks. Here we find a positive but imprecisely estimated interaction term between inflation and the proportion of domestic banks, suggesting that what matters is whether a region's banking sector is integrated with other Russian regions rather than with the rest of the world.

17 See Brown and De Haas (2012) for bank-level evidence on the causal impact of FX denominated customer deposits on FX lending. Their instrumental-variable results suggest that a 10 percentage point increase in FX deposits by customers increases the share of FX loans to households by 7 percent. See also Brown et al. (2013) and Luca and Petrova (2008) for evidence on the impact of FX customer deposits on the share of FX lending to households.
} 


\subsection{Inflation and Mortgage Dollarization}

In Table 3 we replicate our analysis to assess the impact of regional inflation on the dollarization of new mortgage loans. ${ }^{18}$ Because the market for FX mortgages collapsed when the global financial crisis hit Russia in 2008, our sample period is significantly shorter here. We are nevertheless able to fully replicate our earlier results for lending to firms in non-tradable sectors.

Columns 1 and 2 show a strong negative effect of inflation (but not of inflation volatility) on the share of new mortgages extended in FX. This impact is again substantial: a one s.d. increase in regional year-on-year inflation is associated with a 0.16 s.d. increase in mortgage dollarization in the next quarter. Columns 3-6 again show that in regions with relatively closed banking systems, the negative impact of inflation on mortgage dollarization is smaller. In these less-integrated regions banks have to locally intermediate the increased supply of FX deposits when inflation rises. This supply effect counteracts the direct negative effect of inflation on households' demand for FX mortgages.

\section{[Insert Table 3 here]}

\subsection{Robustness}

Table 4 presents various robustness tests. We start by showing a number of replications of our baseline estimates for the impact of inflation on deposit dollarization as reported in column 3 of Table 1 . In column 1 of Table 4 we exclude our standard set of regional time-varying covariates while in column 2 we exclude the dummy variables that control for the entry and exit of regional and multiregional banks over the previous year. Both robustness tests yield similar estimates for Inflation as those in our baseline regressions, both in

\footnotetext{
${ }^{18}$ The average maturity of rouble (FX) mortgages in our dataset is 16.3 (14.5) years.
} 
terms of economic magnitude and statistical significance. In columns 3-8 we replicate these robustness tests for our baseline regression of the effect of inflation on firm and mortgage dollarization. Here as well our baseline estimates are robust to changes in the control variables.

\section{[Insert Table 4 here]}

\section{Conclusions}

In this paper we exploit regional variation in consumer price inflation as well as in the dollarization of household deposits and loans in one of the world's largest currency blocks, the Russian Federation, to analyze the relationship between the stability of the domestic currency and financial dollarization. Our within-country data allow us to empirically isolate the impact of observed inflation on financial dollarization from that of (correlated) nominal exchange rate movements. In the process we also ease concerns about omitted unobserved heterogeneity in economic policies and institutions. We find robust evidence that regions with higher inflation exhibit stronger dollarization of household deposits and weaker dollarization of long-term household credit and credit to firms in the non-tradable sectors. The negative impact of inflation on credit dollarization is weaker in regions where the banking sector is less integrated. In these regions banks have to adjust their lending structure to inflation-driven changes in the currency composition of new deposit inflows.

Our findings shed new light on how inflation impacts on financial intermediation in emerging markets. In particular, while inflation stimulates households to save in a foreign currency it simultaneously leads them to borrow in the domestic currency. Price instability thus tends to create currency mismatches on banks' balance sheets and banks that want to avoid such mismatches can take two courses of action. Firstly, they can try to offload the FX deposits in the form of FX loans. In this way they transfer the currency 
risk to (unhedged) households and firms who may actually prefer domestic currency loans. In this scenario, banks substitute (currency-induced) credit risk for direct balance sheet exposure to currency risk. Secondly, banks can reallocate the FX deposits elsewhere, either abroad or to branches in other regions where the demand for FX loans may be higher. Our results suggest that regionally integrated banks are better able to take this second course of action compared to local banks. Regional banking integration may therefore not only prevent banks from accumulating currency mismatches on their balance sheet, it also reduces the offloading of currency risks on households and unhedged firms and helps them to rebalance the currency composition of their financial portfolio.

\section{REFERENCES}

Bacchetta P. and E. van Wincoop (2006): "Can Information Heterogeneity Explain the Exchange Rate Determination Puzzle?", American Economic Review 96, 552-576.

Basso, H.S., O. Calvo-Gonzalez, and M. Jurgilas (2010): "Financial Dollarization and the Role of Banks and Interest Rates", Journal of Banking and Finance 35, 794-806.

Beck, T. and M. Brown (2014): "Foreign Bank Ownership and Household Credit", Journal of Financial Intermediation, forthcoming.

Beck, G. W., K. Hubrich and M. Marcellino (2009): "Regional Inflation Dynamics Within and across Euro Area Countries and a Comparison with the US", Economic Policy 24, 141-184.

Beckmann, E. and H. Stix (2014), "Foreign Currency Borrowing and Knowledge of Exchange Rate Risk", OeNB Working Paper No. 188, Oesterreichische National Bank, Vienna.

Boyd, J.H., R. Levine and B.D. Smith (2001): "The Impact of Inflation on Financial Sector Performance", Journal of Monetary Economics 47, 221248.

Brown, M., and R. De Haas (2012): "Foreign Banks and Foreign Currency Lending in Emerging Europe", Economic Policy 27, 57-98. 
Brown, M., K. Kirschenmann, and S. Ongena (2014): "Bank Funding, Securitization, and Loan Terms: Evidence from Foreign Currency Lending”, Journal of Money, Credit, and Banking 46(7), 1501-34.

Brown, M., S. Ongena, and P. Yeşin (2011): "Foreign Currency Borrowing by Small Firms", Journal of Financial Intermediation 20, 285-302.

Calvo, G.A. (2001): "Capital Markets and the Exchange Rate: With Special Reference to the Dollarization Debate in Latin America", Journal of Money, Credit, and Banking 33, 312-334.

Craig, B. and C. J. Waller (2004): "Dollarization and Currency Exchange", Journal of Monetary Economics 51, 671-689.

Cremers, M., R. Huang, and Z. Sautner (2011): "Internal Capital Markets and Corporate Politics in a Banking Group", Review of Financial Studies 24:2, $358-401$.

De Gregorio, J., Giovannini, A., and H.C. Wolf (1994): "International Evidence on Tradables and Nontradables Inflation", European Economic Review 38, 1245-1249.

De Nicoló, G., P. Honohan, and A. Ize (2005): "Deposit Dollarization: Causes and Consequences", Journal of Banking \& Finance 29, 1697-1727.

Engineer, M. (2000): "Currency Transaction Costs and Competing Fiat Currencies", Journal of International Economics 52, 116-36.

Fratzscher, M., D. Rime, L. Sarno and G. Zinna (2015): "The Scapegoat Theory of Exchange Rates: The First Tests", Journal of Monetary Economics 70, 1-21.

Froot, K.A. and R. Thaler (1990): "Anomalies: Foreign Exchange", Journal of Economic Perspectives 4, 179-92.

Fuhrer, J.C. and G.R. Moore (1995): "Inflation Persistence," Quarterly Journal of Economics 110, 127-59.

Galai, D. and Z. Wiener (2012): "Credit Risk Spreads in Local and Foreign Currencies", Journal of Money, Credit, and Banking 44(5), 883-901.

Garcia-Escribano, M. and S. Sosa (2011): "What is Driving Financial Dedollarization in Latin America?", IMF Working Paper 11/10.

Gluschenko, K. (2001): "Inter-Regional variability of Inflation Rates", Economics Education and Research Consortium Working Paper Series, Institute of Economics and Industrial Engineering, Novosibirsk.

Gluschenko, K. (2010): "Price Mobility of Locations", Applied Economics Letters 17, 99-103.

Gluschenko, K. (2013): "Dynamics of Regional Price Distribution over 20012010. Working paper (in Russian). 
Imai, M. and S. Takarabe. (2011): "Bank Integration and Transmission of Financial Shocks: Evidence from Japan." American Economic Journal: Macroeconomics 3, 155-183.

Ize, A., and E. Levy-Yeyati (2003): "Financial Dollarization", Journal of International Economics 59, 323-47.

Jensen, J. Bradford and Lori G. Kletzer (2005), "Tradable Services: Understanding the Scope and Impact of Services Outsourcing," Working Paper Series WP05-9, Peterson Institute for International Economics.

Karas, A., W. Pyle, and K. Schoors (2013): "Deposit Insurance, Banking Crises, and Market Discipline: Evidence from a Natural Experiment on Deposit Flows and Rates", Journal of Money, Credit, and Banking 45(1), 179-200.

Lin, S. and H. Ye (2013): "Does Inflation Targeting Help Reduce Financial Dollarization?", Journal of Money, Credit and Banking 45, 1253-74.

Loutskina, E. and P.E. Strahan (2015), "Financial Integration, Housing, and Economic Volatility", Journal of Financial Economics, 115(1), 25-41.

Luca, A., and I. Petrova (2008): "What Drives Credit Dollarization in Transition Economies?", Journal of Banking and Finance 32, 858-69.

Lucas, R.E. (1972): "Expectations and the Neutrality of Money", Journal of Economic Theory 4, 103-124.

Morgan, Donald P., Bertrand Rime, and Philip E. Strahan. (2004): "Bank Integration and State Business Cycles", Quarterly Journal of Economics, 119:4, 1555-1585.

Morris, S. and H.S. Shin (2002): "Social Value of Public Information", American Economic Review 92, 1521-34.

Myatt, D.P. and C. Wallace (2014): "Central Bank Communication Design in a Lucas-Phelps Economy”, Journal of Monetary Economics 63, 64-79.

Nagayasu J. (2011): "Heterogeneity and Convergence of Regional Inflation (Prices)", Journal of Macroeconomics 33, 711-23.

Özbilgin, H.M. (2012): "Currency Substitution, Inflation and Welfare", Journal of Development Economics 99, 358-69.

Phelps, S. (1970), Introduction: The New Microeconomics in Employment and Inflation Theory. In: Archibald, G., Alchian, A.A. and Phelps, E.S. (Eds.), Microeconomic Foundations of Employment and Inflation Theory, Norton, New York, 1-23.

Rancière, R., A. Tornell, and A. Vamvakidis (2010): "Currency Mismatch, Systemic Risk and Growth in Emerging Europe", Economic Policy 25, 597658. 
Uribe, M. (1997): "Hysteresis in a Simple Model of Currency Substitution", Journal of Monetary Economics 40, 185-202.

Valev, N.T. (2010): "The Hysteresis of Currency Substitution: Currency risk vs. Network externalities", Journal of International Money and Finance 29, 224-35.

Vaone A. and G. Ascari (2012): "Regional Inflation Persistence: Evidence from Italy”, Regional Studies 46, 509-23.

Winkelried, D. and P. Castillo (2010): "Dollarization Persistence and Individual Heterogeneity", Journal of International Money and Finance 29, 1596-1618.

World Bank (2013): "Europe and Central Asia Housing Finance Crisis Prevention and Resolution. A Review of Policy Options”, March. 
Table 1

Regional inflation and financial dollarization across Russia

\begin{tabular}{|c|c|c|c|c|c|c|c|c|c|}
\hline & \multicolumn{3}{|c|}{ Deposit dollarization } & \multicolumn{6}{|c|}{ Corporate debt dollarization } \\
\hline & & & & \multicolumn{3}{|c|}{ Non-tradables } & \multicolumn{3}{|c|}{ Tradables } \\
\hline & [1] & [2] & [3] & [4] & [5] & [6] & [7] & [8] & [9] \\
\hline \multirow[t]{2}{*}{ Inflation } & $0.583^{* * *}$ & & $0.492^{* *}$ & $-1.021^{* * * *}$ & & $-1.101 * * *$ & 0.315 & & 0.153 \\
\hline & $(3.06)$ & & $(2.44)$ & $(-2.94)$ & & $(-3.37)$ & $(0.72)$ & & $(0.34)$ \\
\hline \multirow[t]{2}{*}{ Inflation volatility } & & $2.480^{* * *}$ & $1.523^{* * *}$ & & -0.354 & 1.958 & & 4.253 & 3.932 \\
\hline & & (3.89) & (2.58) & & $(-0.14)$ & $(0.78)$ & & $(1.56)$ & (1.39) \\
\hline \multirow[t]{2}{*}{ Change trade openness } & 0.005 & 0.005 & 0.005 & 0.005 & 0.008 & 0.004 & -0.067 & -0.068 & -0.068 \\
\hline & $(0.46)$ & $(0.46)$ & $(0.46)$ & $(0.14)$ & $(0.23)$ & $(0.13)$ & $(-0.92)$ & $(-0.94)$ & $(-0.94)$ \\
\hline \multirow[t]{2}{*}{ Change value tradables } & $-0.052^{* *}$ & $-0.053^{* *}$ & $-0.052^{* *}$ & 0.007 & -0.001 & 0.006 & $0.304^{* *}$ & $0.302^{* *}$ & $0.301^{* *}$ \\
\hline & $(-1.99)$ & $(-2.07)$ & $(-2.0)$ & $(0.08)$ & $(-0.01)$ & $(0.07)$ & (2.49) & $(2.47)$ & $(2.47)$ \\
\hline \multirow[t]{2}{*}{ Change value non-tradables } & -0.024 & -0.021 & -0.025 & 0.035 & 0.035 & 0.035 & -0.007 & -0.007 & -0.007 \\
\hline & $(-0.6)$ & $(-0.51)$ & $(-0.62)$ & $(1.58)$ & (1.6) & $(1.58)$ & $(-0.27)$ & $(-0.27)$ & $(-0.27)$ \\
\hline \multirow[t]{2}{*}{ Change government expenditures } & $-0.065^{* *}$ & $-0.066^{* *}$ & $-0.066^{* *}$ & -0.088 & -0.089 & -0.087 & 0.05 & 0.052 & 0.052 \\
\hline & $(-2.15)$ & $(-2.23)$ & $(-2.20)$ & $(-1.23)$ & $(-1.25)$ & $(-1.21)$ & $(0.41)$ & $(0.43)$ & $(0.43)$ \\
\hline Time FE & Yes & Yes & Yes & Yes & Yes & Yes & Yes & Yes & Yes \\
\hline Bank entry-exit dummies & Yes & Yes & Yes & Yes & Yes & Yes & Yes & Yes & Yes \\
\hline Observations & 2,255 & 2,255 & 2,255 & 2,258 & 2,258 & 2,258 & 2,258 & 2,258 & 2,258 \\
\hline Regions & 71 & 71 & 71 & 71 & 71 & 71 & 71 & 71 & 71 \\
\hline R-squared & 0.35 & 0.35 & 0.36 & 0.03 & 0.03 & 0.03 & 0.03 & 0.03 & 0.03 \\
\hline
\end{tabular}


Table 2

Regional inflation, banking integration, and financial dollarization

\begin{tabular}{|c|c|c|c|c|c|c|c|c|c|c|c|c|}
\hline & \multicolumn{4}{|c|}{ Deposit dollarization } & \multicolumn{8}{|c|}{ Corporate debt dollarization } \\
\hline & & & & & & Non-tr & lables & & & & bles & \\
\hline & [1] & [2] & [3] & [4] & [5] & {$[6]$} & {$[7]$} & [8] & [9] & {$[10]$} & {$[11]$} & [12] \\
\hline \multirow[t]{2}{*}{ Inflation } & $0.542^{* *}$ & $0.551^{* *}$ & $0.477^{*}$ & $0.623 * * *$ & $-1.800 * * *$ & $-1.356^{* * *}$ & $-2.257 * * *$ & $-1.410^{* * *}$ & -0.029 & 0.184 & 0.576 & 0.29 \\
\hline & $(2.16)$ & $(2.46)$ & $(1.67)$ & $(2.72)$ & $(-4.12)$ & $(-3.49)$ & $(-4.00)$ & $(-3.72)$ & $(-0.05)$ & $(-0.36)$ & $(-0.67)$ & $(-0.6)$ \\
\hline \multirow{2}{*}{$\begin{array}{l}\text { Inflation*Proportion local } \\
\text { bank branches (I) }\end{array}$} & -0.175 & & & & $2.305^{* * *}$ & & & & 0.600 & & & \\
\hline & $(-0.33)$ & & & & $(3.05)$ & & & & $(0.46)$ & & & \\
\hline \multirow{2}{*}{$\begin{array}{l}\text { Inflation*Proportion local } \\
\text { bank branches (II) }\end{array}$} & & -0.688 & & & & $2.799 *$ & & & & -0.344 & & \\
\hline & & $(-0.79)$ & & & & $(1.76)$ & & & & $(-0.12)$ & & \\
\hline \multirow{2}{*}{$\begin{array}{l}\text { Inflation*Proportion deposit } \\
\text { funding }\end{array}$} & & & -0.170 & & & & $2.628 * *$ & & & & -0.763 & \\
\hline & & & $(-0.49)$ & & & & $(2.5)$ & & & & $(-0.45)$ & \\
\hline \multirow{2}{*}{$\begin{array}{l}\text { Inflation*Proportion local } \\
\text { bank liabilities }\end{array}$} & & & & $-0.607^{*}$ & & & & $1.377^{* *}$ & & & & -0.614 \\
\hline & & & & $(-1.78)$ & & & & $(2.14)$ & & & & $(-0.59)$ \\
\hline \multirow[t]{2}{*}{ Inflation volatility } & $1.564^{* *}$ & $1.578^{* *}$ & $1.531^{* *}$ & $1.671^{* * *}$ & 1.973 & 1.947 & 2.631 & 1.811 & 3.936 & 3.933 & 3.930 & 3.997 \\
\hline & $(2.61)$ & $(2.61)$ & (2.38) & $(2.71)$ & $(0.79)$ & $(0.78)$ & $(1.03)$ & $(0.74)$ & $(1.40)$ & (1.39) & $(1.24)$ & $(1.40)$ \\
\hline Region FE & Yes & Yes & Yes & Yes & Yes & Yes & Yes & Yes & Yes & Yes & Yes & Yes \\
\hline Time FE & Yes & Yes & Yes & Yes & Yes & Yes & Yes & Yes & Yes & Yes & Yes & Yes \\
\hline Time varying controls & Yes & Yes & Yes & Yes & Yes & Yes & Yes & Yes & Yes & Yes & Yes & Yes \\
\hline Bank entry-exit dummies & Yes & Yes & Yes & Yes & Yes & Yes & Yes & Yes & Yes & Yes & Yes & Yes \\
\hline Observations & 2,255 & 2,255 & 2,191 & 2,255 & 2,258 & 2,258 & 2,258 & 2,258 & 2,258 & 2,258 & 2,258 & 2,258 \\
\hline Regions & 71 & 71 & 71 & 71 & 71 & 71 & 71 & 71 & 71 & 71 & 71 & 71 \\
\hline R-squared & 0.36 & 0.36 & 0.37 & 0.36 & 0.04 & 0.03 & 0.04 & 0.03 & 0.03 & 0.03 & 0.03 & 0.03 \\
\hline
\end{tabular}

Notes: This table shows regression results to estimate the impact of regional consumer price inflation on mortgage and deposit dollarization across Russia's regions. Sample period: Q2 2005-Q2 2008 and Q4 2009-Q2 2014). Robust standard errors are clustered by region and t-statistics appear in parentheses. ***, **, * correspond to the $1 \%, 5 \%$, and $10 \%$ level of significance, respectively. Table A1 in the 2009-Q2 2014). Robust standard errors are 
Table 3

\section{Regional inflation and mortgage dollarization}

\begin{tabular}{|c|c|c|c|c|c|c|}
\hline \multirow[b]{3}{*}{ Inflation } & \multicolumn{6}{|c|}{ Mortgages } \\
\hline & [1] & [2] & [3] & [4] & [5] & {$[6]$} \\
\hline & $\begin{array}{c}-0.321^{* * *} \\
(2.93)\end{array}$ & $\begin{array}{c}-0.346^{* * *} \\
(2.9)\end{array}$ & $\begin{array}{c}-0.622 * * * \\
(3.27)\end{array}$ & $\begin{array}{c}-0.483^{* * *} \\
(3.16)\end{array}$ & $\begin{array}{c}-0.741^{* * *} \\
(3.26)\end{array}$ & $\begin{array}{c}-0.517 * * * \\
(3.85)\end{array}$ \\
\hline $\begin{array}{l}\text { Inflation*Proportion local } \\
\text { bank branches (I) }\end{array}$ & & & $\begin{array}{c}1.097 * * \\
(2.35)\end{array}$ & & & \\
\hline $\begin{array}{l}\text { Inflation*Proportion local } \\
\text { bank branches (II) }\end{array}$ & & & & $\begin{array}{l}1.654 * \\
(1.92)\end{array}$ & & \\
\hline $\begin{array}{l}\text { Inflation*Proportion deposit } \\
\text { funding }\end{array}$ & & & & & $\begin{array}{l}1.078 * * \\
(2.37)\end{array}$ & \\
\hline $\begin{array}{l}\text { Inflation*Proportion local } \\
\text { bank liabilities }\end{array}$ & & & & & & $\begin{array}{c}0.934 * * * \\
(3.00)\end{array}$ \\
\hline Inflation volatility & & $\begin{array}{l}0.696 \\
(0.83)\end{array}$ & $\begin{array}{l}0.782 \\
(0.98)\end{array}$ & $\begin{array}{l}0.691 \\
(0.88)\end{array}$ & $\begin{array}{l}0.636 \\
(0.81)\end{array}$ & $\begin{array}{l}0.768 \\
(0.97)\end{array}$ \\
\hline Region FE & Yes & Yes & Yes & Yes & Yes & Yes \\
\hline Time FE & Yes & Yes & Yes & Yes & Yes & Yes \\
\hline Time varying controls & Yes & Yes & Yes & Yes & Yes & Yes \\
\hline Bank entry-exit dummies & Yes & Yes & Yes & Yes & Yes & Yes \\
\hline Observations & 636 & 636 & 636 & 636 & 636 & 636 \\
\hline Regions & 71 & 71 & 71 & 71 & 71 & 71 \\
\hline R-squared & 0.39 & 0.39 & 0.41 & 0.41 & 0.41 & 0.41 \\
\hline
\end{tabular}

Notes: This table shows regression results to estimate the impact of regional consumer price inflation on mortgage dollarization across Russia's regions. Sample period: Q2 2005-Q2 2008. Robust standard errors are clustered by region and t-statistics appear in parentheses. ***, **, * correspond to the $1 \%, 5 \%$, and $10 \%$ level of significance, respectively. Table A1 in the Appendix contains all variable definitions. 


\section{Table 4}

\section{Regional inflation and financial dollarization across Russia - Robustness}

\begin{tabular}{|c|c|c|c|c|c|c|c|c|}
\hline & \multicolumn{2}{|c|}{ Deposit dollarization } & \multicolumn{6}{|c|}{ Debt dollarization } \\
\hline & & & \multicolumn{2}{|c|}{$\begin{array}{r}\text { Corporate: } \\
\text { tradables }\end{array}$} & \multicolumn{2}{|c|}{$\begin{array}{l}\text { Corporate: } \\
\text { Tradables }\end{array}$} & \multicolumn{2}{|c|}{ Mortgages } \\
\hline & {$[1]$} & {$[2]$} & [3] & [4] & [5] & [6] & [7] & [8] \\
\hline Inflation & $\begin{array}{c}0.396 * * \\
(2.29)\end{array}$ & $\begin{array}{c}0.487^{* *} \\
(2.42)\end{array}$ & $\begin{array}{c}-1.101^{* * *} \\
(-3.42)\end{array}$ & $\begin{array}{c}-1.097 * * * \\
(-3.35)\end{array}$ & $\begin{array}{l}0.163 \\
(0.36)\end{array}$ & $\begin{array}{l}0.124 \\
(0.28)\end{array}$ & $\begin{array}{c}-0.338 * * * \\
(-2.81)\end{array}$ & $\begin{array}{c}-0.332 * * * \\
(-2.83)\end{array}$ \\
\hline Inflation volatility & $\begin{array}{l}1.237 * \\
(1.94)\end{array}$ & $\begin{array}{c}1.511^{* *} \\
(2.55)\end{array}$ & $\begin{array}{l}1.933 \\
(0.78)\end{array}$ & $\begin{array}{l}1.964 \\
(0.79)\end{array}$ & $\begin{array}{l}3.964 \\
(1.38)\end{array}$ & $\begin{array}{l}3.798 \\
(1.34)\end{array}$ & $\begin{array}{l}0.766 \\
(0.96)\end{array}$ & $\begin{array}{l}0.754 \\
(0.92)\end{array}$ \\
\hline Region FE & Yes & Yes & Yes & Yes & Yes & Yes & Yes & Yes \\
\hline Time FE & Yes & Yes & Yes & Yes & Yes & Yes & Yes & Yes \\
\hline Time varying controls & No & Yes & No & Yes & No & Yes & No & Yes \\
\hline Bank entry-exit dummies & Yes & No & Yes & No & Yes & No & Yes & No \\
\hline Observations & 2,624 & 2,255 & 2,271 & 2,258 & 2,272 & 2,258 & 636 & 636 \\
\hline Regions & 71 & 71 & 71 & 71 & 71 & 71 & 71 & 71 \\
\hline R-squared & 0.35 & 0.36 & 0.03 & 0.03 & 0.03 & 0.03 & 0.38 & 0.39 \\
\hline
\end{tabular}

Notes: This table shows OLS regressions to estimate the impact of regional consumer price inflation on dollarization across Russia's regions. Columns 1-3-5-7 report regressions without regional time-varying covariates. Columns 2-4-6-8 report regressions without the dummy variables to control for the entry and exit of regional and multiregional banks over the last year. Robust standard errors are clustered by region. t-statistics appear in parentheses and ***, **, * correspond to the 1\%, 5\%, and 10\% level of significance, respectively. Table A1 in the Appendix contains all variable definitions. 


\section{Figure 1}

\section{Dynamics of regional inflation dispersion across Russia, the Eurozone, and the United States}

These graphs compare the development of inflation dispersion across 71 Russian regions (top left), 12 Eurozone countries (top right), and 25 U.S. urban areas (bottom left). Regional observations measure the deviation from the country-sample mean of the y-o-y CPI. Source: Central Bank of the Russian Federation, U.S. Bureau of Labor Statistics, and Eurostat.
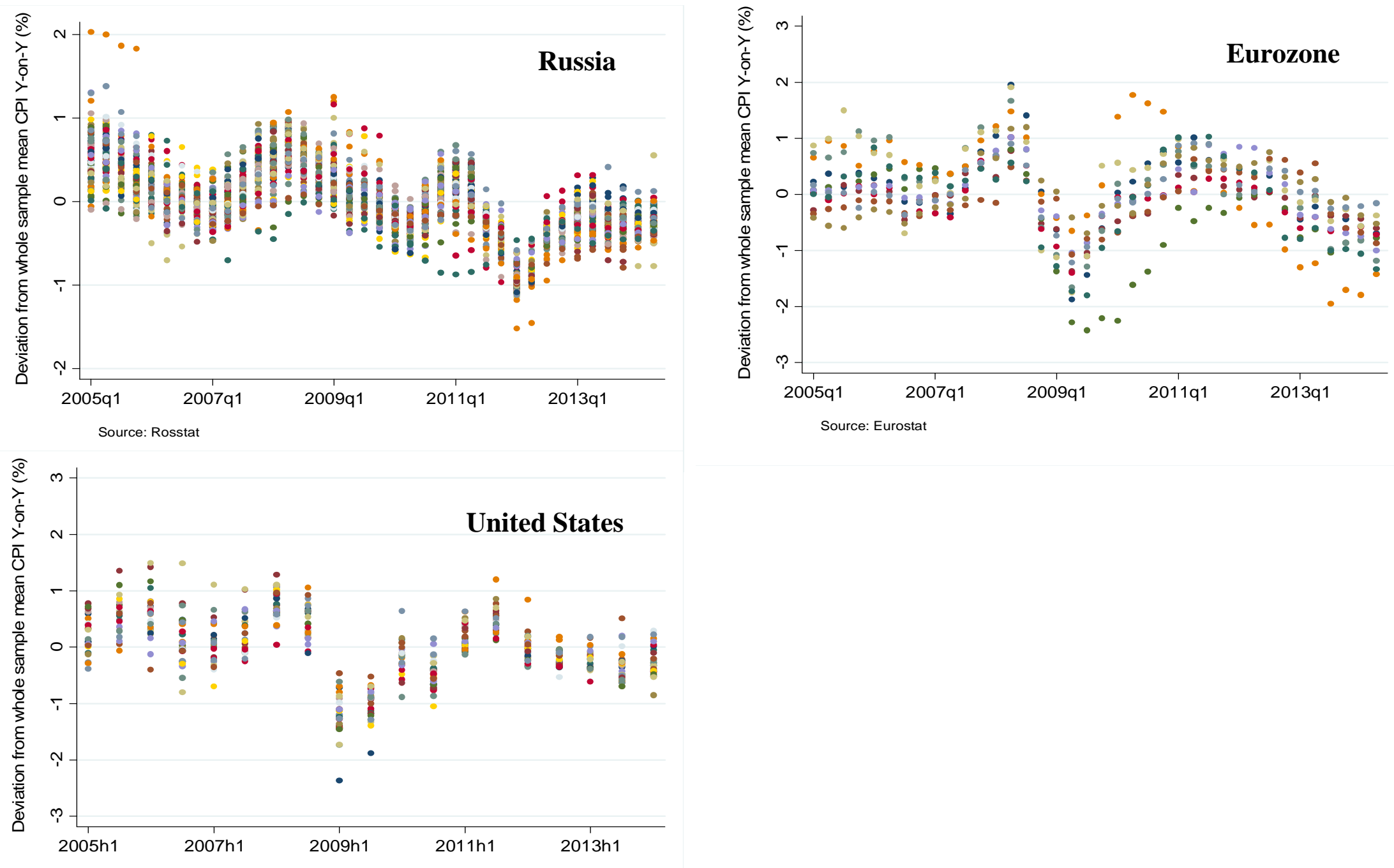

Source: BLS 
Figure 2 inflation and dollarization across Russia

These maps of the Russian regions show average consumer price inflation (upper map); average share of new bank deposits denominated in a foreign currency (middle map); and the average share of new lending to firms in non

Average inflation

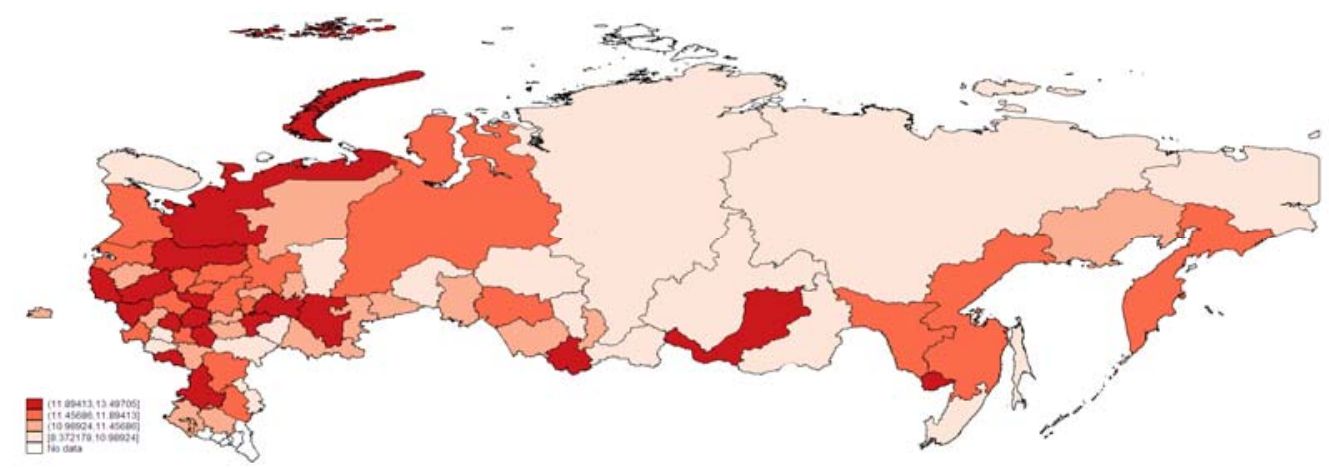

Average share of new FX deposits

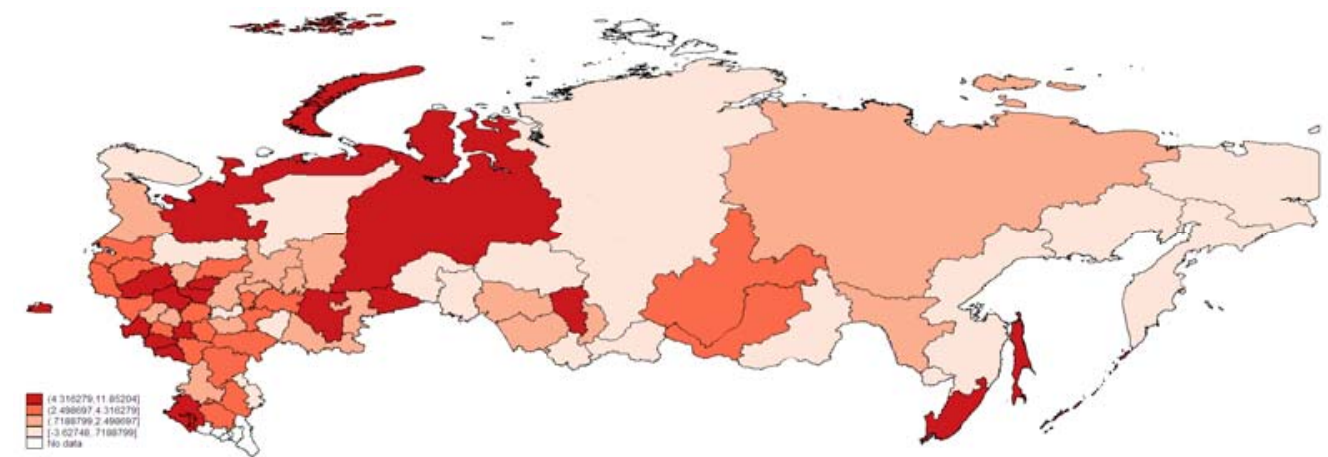

Average share of new FX lending to firms in non-tradable sectors

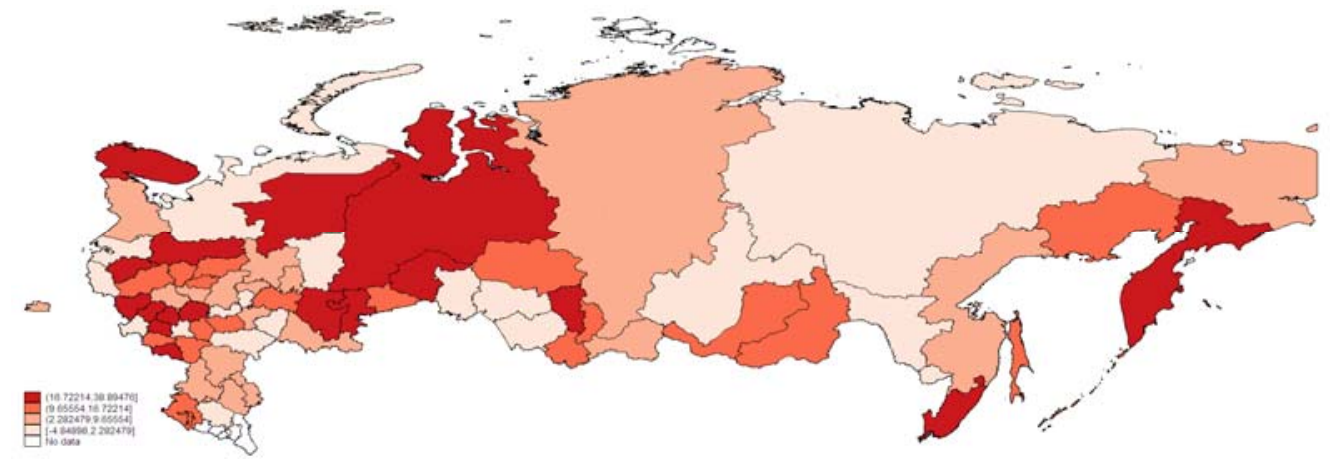


Table A1

Variable definitions and data sources

Dependent variables:

Deposit dollarization

Mortgage dollarization

Definition

Firm debt dollarization non-tradables

Quarterly change in new FX household deposits with banks in a region/quarterly change in total new household deposits with banks in a region

Quarterly change in new FX mortgage lending by banks in a region/quarterly change in total new mortgage lending by banks in a region

Firm debt dollarization tradables

Quarterly change in new FX credit to firms in non-tradable sectors in a region/quarterly change in total new credit to firms in non-tradable sectors in a region

Quarterly change in new FX credit to firms in tradable sectors in a region/quarterly change in total new credit to firms in tradable sectors in a region

CBR $\%$

Independent variables:

Inflation

One quarter lagged year-on-year change of the price of a fixed basket of consumer goods (same basket applies to all Russian regions)

CBR $\%$

Inflation volatility

Change trade openness

Change value tradables

Moving standard deviation of regional monthly inflation over the past 12 months (one quarter lagged)

Quarterly growth of regional trade with foreign countries defined as the average of the sum of regional world exports plus regional world imports

Quarterly growth of regional value added of the manufacturing and commodity-extraction industries

Change value non-tradables

Change government expenditures

Quarterly growth of regional value added of the construction, electricity generation, services, retail, and wholesale trade industries

Quarterly growth of regional government spending

Proportion local bank branches (I)

Number of banks registered in the region as a proportion of the total number of banks in the region (i.e. both local banks and branches of inter-regional banks) in $2004-05$

CBR $\%$

CBR \%

Proportion local bank branches (II)

Number of branches and all offices of banks registered in the region as a proportion of the total number of branches and all offices of banks in the region (i.e. both local bank branches and offices and branches and offices of inter-regional banks) in 2013

Proportion local bank liabilities

Liabilities of banks registered in a region as a proportion of total liabilities of all banks operating in a region in 2004-05 (liabilities include accounts of firms and government bodies, firm deposits, household deposits, and loans from other banks)

Proportion deposit funding

Customer deposit funding as a proportion of banks' total funding (defined as customer deposits+ firm deposits + interbank borrowing) in 2004-05

Rosstat \%

Rosstat \%

Rosstat \%

Rosstat \%

Rosstat \%

Rosstat \%

CBR Share

BEPS II Share

CBR Share

CBR Share

Notes: CBR and Rosstat are the Central Bank and the Federal State Statistics Service of the Russian Federation, respectively. All dependent variables are on a constant currency basis by adjusting the reported FX amounts using the exchange-rate change over the reported period. BEPS II: EBRD Banking Environment and Performance Survey II. 
Table A2

Summary statistics

\begin{tabular}{lcccccc}
\hline \hline & Obs. & Mean & Median & St. dev. & Min & Max \\
\cline { 2 - 7 } Dependent variables: & & & & & & \\
Deposit dollarization & 2,624 & 2.52 & 1.48 & 17.94 & -67.75 & 72.65 \\
Mortgage dollarization & 636 & 10.23 & 7.31 & 9.38 & 0.00 & 54.72 \\
Firm debt dollarization (non-tradables) & 2,271 & 10.45 & 0.21 & 35.36 & -50.35 & 98.39 \\
Firm debt dollarization (tradables) & 2,272 & 16.16 & 9.78 & 48.86 & -82.63 & 98.91 \\
Independent variables: & & & & & & \\
Inflation & 2,627 & 11.42 & 11.16 & 4.80 & -6.02 & 35.06 \\
Inflation volatility & 2,627 & 1.20 & 1.13 & 0.50 & 0.25 & 2.27 \\
Change trade openness & 2,258 & 4.50 & 5.76 & 35.61 & -118.34 & 128.48 \\
Change value tradables & 2,556 & 4.79 & 6.69 & 20.19 & -58.90 & 63.66 \\
Change value non-tradables & 2,556 & 8.12 & 7.53 & 32.61 & -47.12 & 31.84 \\
Change government expenditures & 2,627 & 16.90 & 5.76 & 13.89 & -14.62 & 61.65 \\
Proportion local bank branches (I) & 71 & 0.29 & 0.27 & 0.15 & 0.00 & 0.73 \\
Proportion local bank branches (II) & 71 & 0.09 & 0.07 & 0.08 & 0.00 & 0.50 \\
Proportion local bank liabilities & 71 & 0.23 & 0.17 & 0.19 & 0.00 & 0.94 \\
Proportion deposit funding & 71 & 0.40 & 0.39 & 0.15 & 0.00 & 0.68 \\
\hline
\end{tabular}

